\title{
Human Parathyroid Hormone
}

\author{
IMMUNOLOGICAL CHARACTERIZATION OF ANTIBODIES AGAINST \\ A GLANDULAR EXTRACT AND THE SYNTHETIC AMINO-TERMINAL \\ FRAGMENTS 1-12 AND 1-34 AND THEIR USE IN THE DETERMINATION \\ OF IMMUNOREACTIVE HORMONE IN HUMAN SERA
}

\author{
Jan A. Fischer, Ulrich Binswanger, and Felix M. Dietrich \\ From the Research Laboratory for Calcium Metabolism, Departments of \\ Orthopedic Surgery and Medicine, University of Zurich, 8008 Zurich, and \\ Research Department, Pharmaceuticals Division, CIBA-GEIGY Limited, \\ 4002 Basle, Switzerland
}

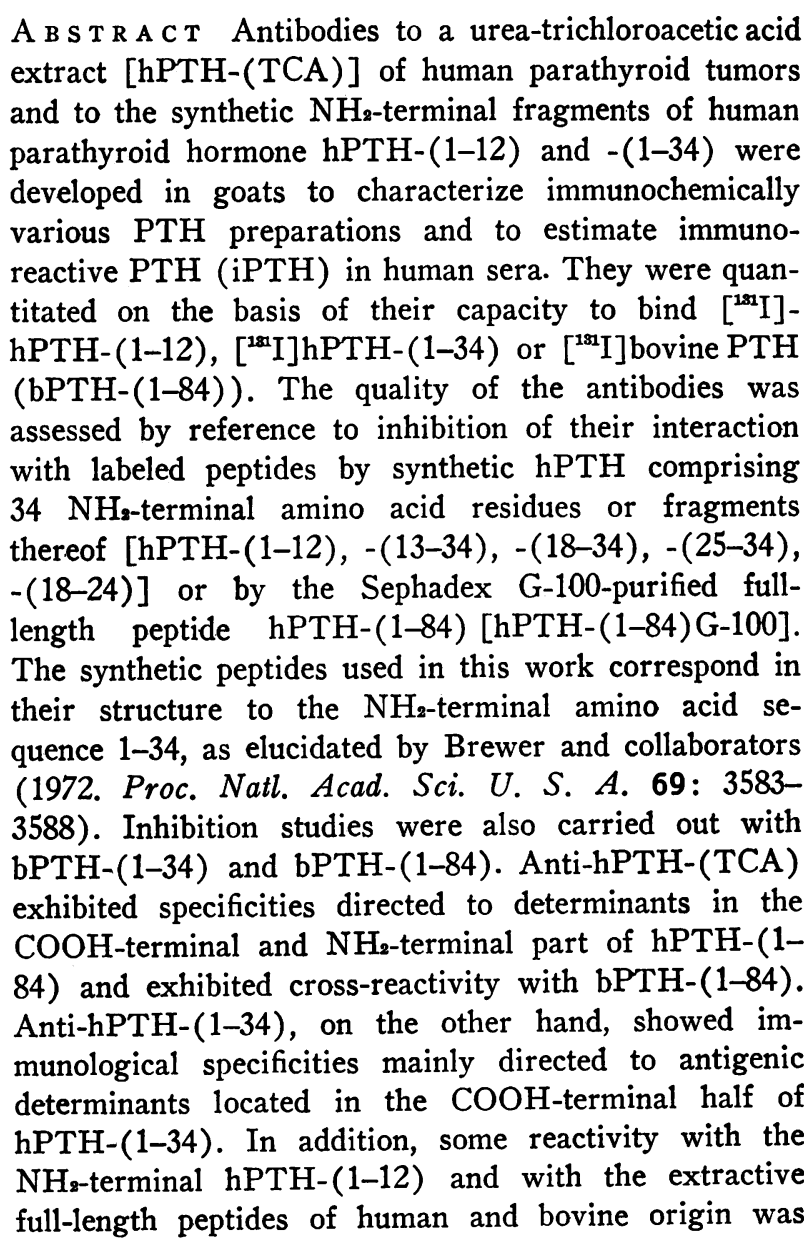

Part of this work has been published in abstract form in: 1974. Clin. Res. $22: 467$.

Received for publication 3 June 1974 and in revised form 13 August 1974. observed. Antibodies to hPTH-(1-12) cross-reacted with hPTH-(1-34) and -(1-84)G-100.

iPTH was radioimmunologically determined in human sera by the following systems: (a) $\left[{ }^{191} \mathrm{I}\right] \mathrm{bPTH}-$ (1-84), anti-hPTH-(TCA) and hPTH-(1-84)G-100 as standard; (b) [ $\left.{ }^{131} \mathrm{I}\right] \mathrm{hPTH}-(1-34)$, anti-hPTH-(1$34)$ and hPTH-(1-34) as standard. With system (a), $\mathrm{COOH}$-terminal fragments of hPTH-(1-84) having a molecular weight of approximately 7,000 were detected, and there was an almost total discrimination of serum iPTH levels in normal and in hyperparathyroid subjects. With system $(b)$, on the other hand, several molecular species of iPTH were detected, including a component larger than hPTH-(1-84) and others similar to hPTH-(1-84) and to a fragment co-eluting with the $\mathrm{NH}_{2}$-terminal fragment hPTH-(1-34). When serum iPTH was assayed in system $(b)$, there was a large overlap of iPTH levels in control subjects and in patients with primary hyperparathyroidism.

\section{INTRODUCTION}

Immunoreactive parathyroid hormone (iPTH) ${ }^{1}$ in man has been estimated by competitive binding technics using

${ }^{1}$ Abbreviations used in this paper: $\mathrm{B} / \mathrm{F}$, ratio of antibody-bound [ $\left.{ }^{131} \mathrm{I}\right] \mathrm{PTH}$ and free [181 I]PTH; bPTH, bovine parathyroid hormone; dilution-50, serum dilution giving $50 \%$ binding of the labeled peptides; EGTA, ethylene glycolbis ( $\beta$-aminoethyl ether) $-N, N^{\prime}$-tetraacetic acid; hPTH, human parathyroid hormone; hPTH-(1-84)G-100, hPTH(TCA) additionally gel filtrated through Sephadex G-100; hPTH-(TCA), a urea-trichloroacetic acid extract of human parathyroid tumors; ID 50 , inhibition dose-50, amount of inhibitor required for a $50 \%$ reduction of specific binding of trace-labeled antigen to antibody; iPTH, immunoreactive parathyroid hormone; pPTH, porcine PTH. 
exclusively heterologous systems (1-8). These radioimmunoassays are based on the ability of human iPTH to compete with radiolabeled bovine PTH (bPTH) for binding to an antiserum raised against bPTH or porcine PTH ( $\mathrm{pPTH})$. The estimation of $\mathrm{PTH}$ in human serum is problematic mainly for two reasons. Apart from structural differences between PTH's originating from several species and the varying degree of immunological cross-reactivity between these peptides and human PTH (hPTH), the main obstacle to the measurement of absolute concentrations of the hormone is the presence in the circulation of PTH peptides of different molecular weight that react with antisera to PTH differently. The immunological heterogeneity of iPTH in human plasma was first demonstrated by Berson and Yalow (9), and a similar dissociation in immunoreactivity between serum and glandular PTH was described by Arnaud, Tsao, and Oldham (10). The concept suggesting the presence of more than one molecular-weight species of PTH in the circulation was subsequently confirmed (11-14). Since then, many attempts have been made to determine the immunochemical properties of PTH obtained from man (1519).

Recently, hPTH was isolated from parathyroid tumors. Its $\mathrm{NH}_{2}$-terminal amino acid sequence (residues 1-34) was determined by Brewer, Fairwell, Ronan, Sizemore, and Arnaud (20), and the biologically active $(21,22) \mathrm{hPTH}-(1-34)$ was synthesized by Andreatta et al. (22). Subsequently, we gave a preliminary account of the immunochemical properties of the synthetic $\mathrm{NH}_{2}$-terminal PTH fragment (23). Most recently, Niall et al. (24) reported for $\mathrm{hPTH}$ a $\mathrm{NH}_{2}$-terminal amino acid sequence comprising residues 1-37 which differs at three positions from the sequence reported by Brewer and co-workers $(20)$. The reason for this discrepancy is not yet clear. One possibility is that there are several isohormones of $\mathrm{hPTH}$, as suggested by the results of O'Riordan et al. (25). The 1-34 sequence of Niall et al. (24) was also synthesized (26).

In the present investigation, antisera to a urea-trichloroacetic acid extract of human parathyroid tumors as well as to synthetic fragments hPTH-(1-12) and -(1-34) (22) based on the structure of Brewer et al. (20) have been studied and their immunological specificity has been analyzed. In addition, it has been shown that some of these antibodies are useful for quantitating iPTH levels in the sera of patients exhibiting primary hyperparathyroidism as well as in sera of control subjects.

\section{METHODS}

Peptides. A urea-trichloroacetic acid extract [hPTH(TCA) ] (27) of human parathyroid tumors (kindly provided by the European PTH Study Group) was prepared

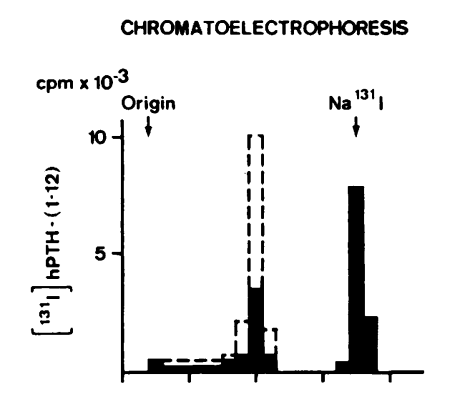

GEL FILTRATION $(p \cdot 10)$
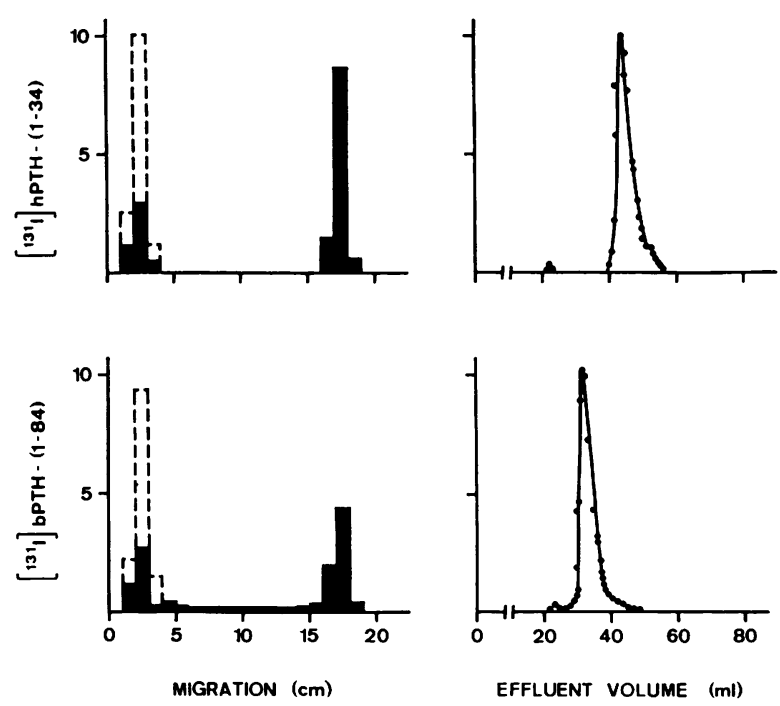

FIGURE 1 Properties of ${ }^{191}$ I-labeled synthetic hPTH-(112) and -(1-34), and extracted bPTH-(1-84). Chromatoelectrophoretograms (left) of iodinated mixtures before (solid areas) and after purification (open areas) (for details see text). Gel filtration (right) of $1 \mathrm{ml}$ iodination mixture after purification on Bio-Gel P-10 column, $1 \times 100$ $\mathrm{cm}, 0.2 \mathrm{M}$ ammonium acetate $(\mathrm{pH} 4.7)$ and human serum albumin $(2.5 \mathrm{mg} / \mathrm{ml})$ as eluant; $1.5 \mathrm{ml} / \mathrm{h}$ flow rate; $0.75-\mathrm{ml}$ fractions. $\mathrm{Na}^{1 \mathrm{1s}} \mathrm{I}$ represents less than $0.2 \%$ of the radioactivity.

by Dr. A. Jöhl, CIBA-GEIGY. hPTH-(1-84) was also a urea-TCA hPTH extract additionally gel-filtrated with Sephadex G-100 (Pharmacia, Uppsala, Sweden) [hPTH(1-84) G-100] and was donated by Dr. C. D. Arnaud, Mayo Clinic, Rochester, Minn. The estimated purity was $10 \%$ in comparison to homogenous hPTH- (1-84)., 3 Synthetic hPTH-(1-34) [hPTH-(1-34)] was the preparation synthesized by fragment condensation procedure described by Andreatta et al. (22). The fragments thereof, hPTH$(1-12),-(13-14),-(18-34),-(25-34)$, and -(18-24), were prepared from the corresponding protected intermediates obtained in the synthesis of hPTH-(1-34) by Drs. R. H. Andreatta, H. Hartmann, B. Kamber, and W. Rittel (CIBA-GEIGY). Synthetic bPTH-(1-34) was purchased from Beckman Instruments, Inc., Spinco Div., Palo Alto,

${ }^{2}$ C. D. Arnaud. Personal communication.

${ }^{3}$ Whenever hPTH-(1-84)G-100 is used in the present context, the actual amount of hPTH-(1-84) is calculated.

Antibodies to Human Parathyroid Hormone 1383 
TABLE I

The Immune Response to Extracted hPTH

\begin{tabular}{|c|c|c|c|c|c|c|c|c|c|c|}
\hline \multirow[b]{2}{*}{ Goat } & \multirow[b]{2}{*}{ Antigen* } & \multicolumn{9}{|c|}{ Day of blood sampling } \\
\hline & & 26 & 56 & 106 & 113 & 117 & 211 & 222 & 253 & 306 \\
\hline \multicolumn{11}{|c|}{$\mu g$} \\
\hline \multicolumn{11}{|c|}{ Binding of synthetic $\left[{ }^{131} \mathrm{I}\right] \mathrm{hPTH}-(1-34)$} \\
\hline 1 & 800 & $<10 \ddagger$ & $<10$ & $<10$ & 20 & 20 & ND & ND & $\mathrm{ND}$ & 35 \\
\hline 2 & 800 & $<10^{\circ}$ & $<10$ & $<10$ & $<10$ & $<10$ & ND & ND & ND & $<10$ \\
\hline 3 & 800,100 & $<10$ & $<10$ & $<10$ & $<10$ & 20 & 100 & 80 & 80 & 100 \\
\hline \multicolumn{11}{|c|}{ Binding of extracted $\left[{ }^{131} \mathrm{I}\right] \mathrm{bPTH}-(1-84)$} \\
\hline 1 & 800 & $<10$ & $<10$ & $<10$ & 100 & 700 & ND & ND & ND & 200 \\
\hline 2 & 800 & 10 & 10 & 10 & 50 & 100 & ND & ND & ND & 90 \\
\hline 3 & 800,100 & $<10$ & $<10$ & $<10$ & 50 & 100 & 400 & 200 & 160 & 85 \\
\hline
\end{tabular}

ND, not done.

${ }^{*}$ hPTH-(TCA), total extract injected on days 0 and 107. Goat 3 received additional injections of $100 \mu \mathrm{g}$ each on days 205 and 244. All the goats received a last injection of $800 \mu \mathrm{g}$ on day 300 .

$\ddagger$ Reciprocal dilution-50.

Calif., and purified bPTH-(1-84) (lot 147865) was obtained from Wilson Laboratories, Chicago, Ill. bPTH-(184) was assumed to have a purity of $79 \%$, on the basis of the radioimmunological comparison with bPTH isohormone I standard 71/324 (Medical Research Council, London, England).

Gel filtration of peptides or sera. Columns of Bio-Gel P-6 (200-400 mesh) (Bio-Rad Laboratories, Richmond, Calif.), $1 \times 50 \mathrm{~cm}$, were used for the purification of [ $\left.{ }^{181} \mathrm{I}\right]$ hPTH-(1-12), and columns of Bio-Gel P-10 (200-400 mesh), $1 \times 100 \mathrm{~cm}$, were used for the gel filtration of the purified labeled [ $\left.{ }^{191} \mathrm{I}\right] \mathrm{hPTH}-(1-12)$ and $-(1-34)$ and [ $\left.{ }^{181} \mathrm{I}\right]-$ bPTH-(1-84), as well as of hPTH-(TCA), hPTH-(1-34), and hyperparathyroid sera. The columns were equilibrated with eluant consisting of $0.2 \mathrm{M}$ ammonium acetate ( $\mathrm{pH}$ 4.7) and human serum albumin (Central Laboratories of the Swiss Red Cross, Berne, Switzerland) $(2.5 \mathrm{mg} / \mathrm{ml})$ at $4^{\circ} \mathrm{C}$. The void volume was determined with blue dextran (Pharmacia) and the salt volume with $\mathrm{Na}^{181} \mathrm{I}$. For purification of [20I]hPTH-(1-12) $0.2-0.5 \mathrm{ml}$ samples were used (flow rates $5-7 \mathrm{ml} / \mathrm{h}, 0.5-1 \mathrm{ml}$ fractions), whereas gel filtration of hPTH-(TCA), -(1-34), and hyperparathyroid sera was accomplished with $1-\mathrm{ml}$ samples to which [ $\left.{ }^{181} \mathrm{I}\right]-$
bPTH-(1-84), [ $\left.{ }^{181} \mathrm{I}\right] \mathrm{hPTH}-(1-34), \quad-(1-12)$, and $\mathrm{Na}^{181} \mathrm{I}$ were added (flow rates $1.4-1.6 \mathrm{ml} / \mathrm{h}, 0.7-0.8-\mathrm{ml}$ fractions). Radioactivity was determined in an automatic gamma-well spectrometer (Nuclear-Chicago Corp., Des Plaines, IIl.). The amount of each labeled peptide marker was kept low enough not to interfere with radioimmunological determinations.

Trace-labeling of peptides. Synthetic hPTH-(1-12), - (1$34)$, and purified bPTH-(1-84) (the latter being chosen instead of highly purified hPTH-(1-84) which was not available in sufficient quantities) were radioiodinated by a modified Hunter and Greenwood chloramine- $T$ procedure (28) as described by Berson and Yalow (29). $\mathrm{Na}^{181} \mathrm{I}$ was obtained from The Radiochemical Centre, Amersham, England and used on the day of arrival. The specific activities of [ $\left.{ }^{131} \mathrm{I}\right] \mathrm{hPTH}-(1-12),-(1-34)$, and [131] $\mathrm{bPTH}-(1-84)$ were estimated to range between $130-220 \mathrm{mCi} / \mathrm{mg}, 150-300$ $\mathrm{mCi} / \mathrm{mg}$, and $200-500 \mathrm{mCi} / \mathrm{mg}$, respectively, and were assessed by chromatoelectrophoresis (30) carried out at room temperature (Fig. 1). In the absence of tyrosine residues in hPTH-(1-12) and - (1-34), the ${ }^{181} \mathrm{I}$ presumably bound to the histidine (s). [ $\left.{ }^{181} \mathrm{I}\right] \mathrm{hPTH}-(1-34)$ and $\left[{ }^{121} \mathrm{I}\right]-$ bPTH-(1-84) were purified on cellulose Whatman-CF1

TABLE II

Qualitative Properties of Antibodies against Extracted hPTH

\begin{tabular}{|c|c|c|c|c|c|c|c|}
\hline \multirow[b]{2}{*}{ Goat* } & \multirow{2}{*}{$\begin{array}{l}\text { Ligand: } \\
\text { Inhibitor: }\end{array}$} & \multicolumn{3}{|c|}{$\left[{ }^{181} \mathrm{I}\right] \mathrm{hPTH}-(1-34)$} & \multicolumn{3}{|c|}{$\left[{ }^{181} I\right] \mathrm{bPTH}-(1-84)$} \\
\hline & & hPTH-(1-84)G-100 & hPTH-(1-34) & bPTH-(1-84) & hPTH-(1-84)G-100 & hPTH-(1-34) & bPTH-(1-84) \\
\hline & & \multicolumn{3}{|c|}{$n g$} & \multicolumn{3}{|c|}{$n g$} \\
\hline 1 & & $20 \ddagger$ & 3.10 & 22 & 1.21 & $>5,000$ & 0.56 \\
\hline 2 & & ND & ND & ND & 1.58 & $>5,000$ & 1.46 \\
\hline 3 & & 8.1 & 0.59 & 29 & 0.80 & $>5,000$ & 0.41 \\
\hline
\end{tabular}

ND, not done.

* Immunized as indicated in Table I. Antisera to hPTH-(TCA) were obtained on day 117.

$\ddagger$ Inhibition dose-50. 

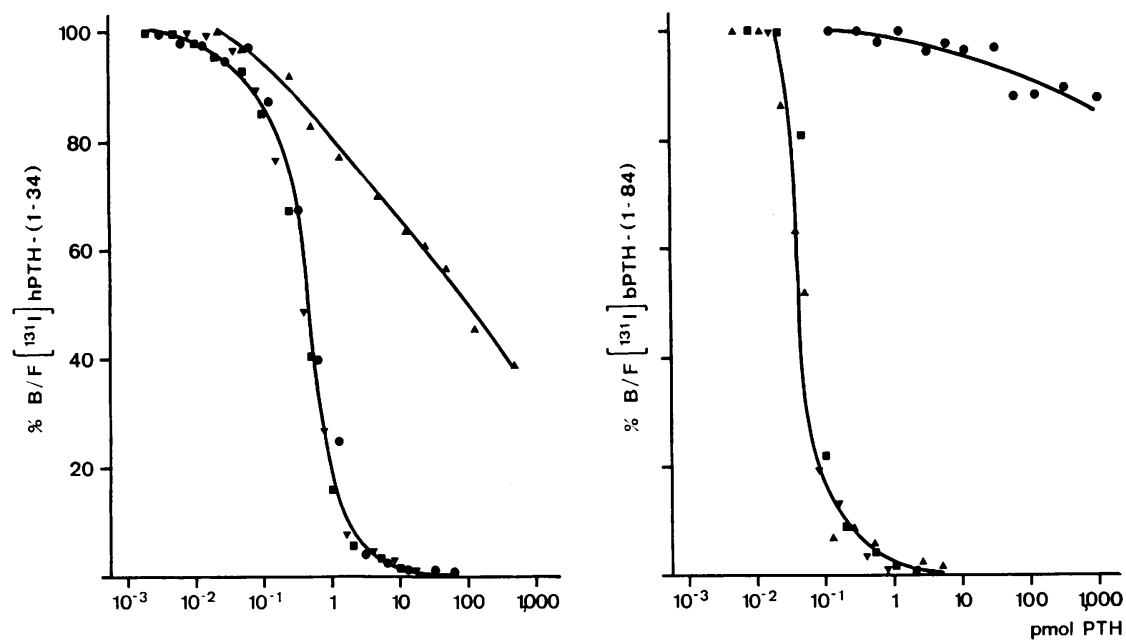

FIgURe 2 Qualitative properties of antibodies to extracted hPTH-(TCA). Inhibition of specific binding of $\left.{ }^{131} \mathrm{I}\right] \mathrm{hPTH}-(1-34)$ (left) and of [ $\left.{ }^{121} \mathrm{I}\right] \mathrm{bPTH}-(1-84)$ (right) to anti-hPTH(TCA) obtained from goat 3 , day 306 (see Table I) and diluted 1:400. Ordinate: percent initial B/F (without inhibitor added). Inhibitors: hPTH-(1-34) (๑), hPTH-(1-84)G-100 $(\boldsymbol{\nabla}), \mathrm{hPTH}-(\mathrm{TCA})(\boldsymbol{\square}), \mathrm{bPTH}-(1-84)(\boldsymbol{\Delta})$.

(Reeve Angel, London, England) (30), and [ $\left.{ }^{131} \mathrm{I}\right] \mathrm{hPTH}-$ (1-12) was purified on Bio-Gel P-6 columns as described above. Fig. 1 demonstrates that the labeled peptides consisted of single components in chromatoelectrophoretic and gel filtration analysis. Less than $0.2 \%$ of the radioactivity represents $\mathrm{Na}^{131} \mathrm{I}$. In contrast to [ $\left.{ }^{181} \mathrm{I}\right] \mathrm{bPTH}-(1-84)$ and [ ${ }^{181}$ I]bPTH-(1-34), which remained at the origin on chromatoelectrophoresis, [ $\left.{ }^{181} \mathrm{I}\right] \mathrm{hPTH}-(1-12)$ migrated towards the anode, which probably reflects nonspecific binding to serum proteins (30). Incubation with excess anti-hPTH(1-34) showed that $89-92 \%$ of [18I] I PTH-(1-34) was specifically bound, whereas $80-84 \%$ of [191 I]hPTH-(1-12) and [18I]bPTH-(1-84) was bound to anti-hPTH-(1-12) and anti-bPTH-(1-84), respectively. In the presence of $10-50 \%$ serum but without antiserum added to the incubation mixture, less than $1 \%$ of [ $\left.{ }^{180} \mathrm{I}\right] \mathrm{hPTH}-(1-12), 7 \%$ of [181] IhPTH-(1-34), and $12 \%$ of $\left[{ }^{130} \mathrm{I}\right] \mathrm{bPTH}-(1-84)$ were not absorbed to dextran-coated charcoal.

Immunization and quantitation of antibodies. The antigens hPTH-(TCA), hPTH-(1-12), - (1-34), and bPTH(1-84) were dissolved in $0.01 \mathrm{~N}$ acetic acid, admixed with $2 \%$ aluminum hydroxide (Alhydrogel, Superfos Export Company a/s, Copenhagen, Denmark) and emulsified with an equal volume of complete Freund's adjuvant (Difco Laboratories, Detroit, Mich.) with a Sorvall Omnimixer (Ivan Sorvall, Inc., Newton, Conn.). A total amount of $0.5-1.0 \mathrm{ml}$ of the final adjuvant mixture containing antigen as indicated under Results was injected into 15-20 intradermal sites of female goats $(25-30 \mathrm{~kg})$. Simultaneously, $0.5 \mathrm{ml}$ of a Bordetella pertussis vaccine $\left(4 \times 10^{10} \mathrm{~B}\right.$. pertussis phase I organisms per $\mathrm{ml}$, Swiss Institute of Sera and Vaccines, Berne, Switzerland) was administered subcutaneously at a single site. Blood samples were obtained from the jugular vein and allowed to clot at room temperature. The sera were heat inactivated $\left(56^{\circ} \mathrm{C}, 30 \mathrm{~min}\right)$ and stored in small portions at $-20^{\circ} \mathrm{C}$ until use.

Antibodies were quantitated on the basis of their capacity to bind trace-labeled antigen. The incubation volume was $0.5 \mathrm{ml}$ containing about $15,000 \mathrm{cpm}$ of trace-labeled
hPTH-(1-12) or -(1-34) or bPTH-(1-84). The diluent generally consisted of hypoparathyroid serum diluted $1: 10$ (when patient sera were analyzed for iPTH, this serum was diluted $1: 5$ ) in $0.05 \mathrm{M}$ sodium barbital buffer, $\mathrm{pH}$ 8.6. Some incubations were performed at $\mathrm{pH} 5.0$ in $0.05 \mathrm{M}$ sodium acetate and at $\mathrm{pH} 6.2$ and 7.4 in $0.05 \mathrm{M}$ sodium phosphate buffer. The effect of $\mathrm{pH}$ was studied in a medium containing $2.5 \mathrm{mg} / \mathrm{ml}$ human serum albumin instead of serum. Antisera were tested for specific binding of the radioiodinated peptides at multiple dilutions. Incubations were carried out for 3 days at $4^{\circ} \mathrm{C}$. Control tubes containing comparable amounts of nonimmune goat serum were incubated simultaneously. Separation of antibody-bound from free PTH was accomplished with dextran-coated charcoal $(4,31)$. Radioactivity was determined in both supernates and sediments. The ratio of antibody-bound [181 I]PTH and free [ $\left.{ }^{12} \mathrm{I}\right] \mathrm{PTH}(\mathrm{B} / \mathrm{F})$ was calculated by correcting for non-antibody-associated radioactivity present in the supernate. The amount of antibodies present in each antiserum was determined by graphically estimating the "dilution-50"

TABLE III

Purity of Extracted hPTH

\begin{tabular}{|c|c|c|c|}
\hline \multirow[b]{2}{*}{ Goat* } & \multicolumn{3}{|c|}{ Inhibitor } \\
\hline & hPTH-(TCA) & hPTH-(1-84)G-1008 & Purity \\
\hline & & $n g$ & $\%$ \\
\hline 1 & $109 \|$ & 1.21 & 1.1 \\
\hline 2 & 152 & 1.58 & 1.0 \\
\hline 3 & 121 & 1.21 & 1.0 \\
\hline
\end{tabular}

System: [1'I]bPTH-(1-84), anti-hPTH-(TCA), and hPTH-(1-84)G-100 as standard.

* Immunized as indicated in Table I. Antisera to hPTH-(TCA) were obtained on day 117.

$\ddagger$ Total extract.

$\$$ See footnote 3 .

In Inhibition dose-50.

Antibodies to Human Parathyroid Hormone 
TABLE IV

Quantitative and Qualitative Properties of Antibodies against Synthetic $\mathrm{NH}_{2}$-terminal Fragment -(1-12) of $h P T H$

\begin{tabular}{rcrrrrrrrr}
\hline & & \multicolumn{8}{c}{ Sera obtained on days: } \\
\cline { 2 - 10 } Goat & Antigen* & 26 & 56 & & 106 & 113 & 116 & \\
\hline & $\mu g$ & & & $n g$ & & & $n g$ & & $n g$ \\
4 & 40 & $<10 \ddagger$ & $<10$ & & $<10$ & $<10$ & & $<10$ & \\
5 & 40 & $<10$ & $<10$ & & $<10$ & $<10$ & & $<10$ & \\
6 & 40 & $<10$ & $<10$ & & $\dagger$ & & & & \\
7 & 330 & $<10$ & 20 & $>100 \S$ & $<10$ & $<10$ & & $<10$ & \\
8 & 330 & $<10$ & 50 & 27.4 & $<10$ & 160 & ND & 400 & 0.4 \\
9 & 330 & $<10$ & $<10$ & & $<10$ & 70 & ND & 60 & 30.3 \\
\hline
\end{tabular}

ND, not done.

* Injected on days 0 and 107.

$\ddagger$ Reciprocal dilution-50.

\$ Inhibition dose-50.

$\dagger$ Goat 6 died.

values as defined as the dilution of antiserum yielding $50 \%$ specific binding of the iodinated peptides.

Qualitative properties of antibodies and radioimmunoassay of $i P T H$ in human sera. Inhibition by various PTH preparations of the primary interaction between antibodies and trace-labeled peptides was determined with dilutions of antisera yielding $30-40 \%$ specific binding in the absence of inhibitor. Graded amounts of inhibitors were preincubated for 3-4 days at $4^{\circ} \mathrm{C}$ (total volume $0.3 \mathrm{ml}$ ). Then $0.2 \mathrm{ml}$ diluent containing the trace-labeled peptide was added, and the mixture was incubated for another 3 days. The amount of radioactivity specifically bound to antibody in the presence of inhibitors was compared with the control to which no inhibitor had been added. Each standard or unknown B/F ratio is expressed as a percentage of the initial $B / F$ ratio. The amounts of inhibitor required to reduce specific binding to $50 \%$ (IDso) were determined from graphs such as shown in Fig. 4.

iPTH was determined in eluates from gel filtration experiments. It was shown that ammonium acetate in concentrations as great as $0.02 \mathrm{M}$ did not influence the $\mathrm{B} / \mathrm{F}$ ratios. If required, effluent fractions were lyophilized.

iPTH was estimated in peripheral human serum. Calcium was determined by automatic ethylene glycol-bis ( $\beta$-aminoethyl ether) $-N, N^{\prime}$-tetraacetic acid (EGTA) titration with calcein as an indicator (Marius Calcium Titrator, Utrecht, The Netherlands) (coefficient of variation $0.8 \%$ ) and ionized calcium by a flow-through electrode system (Orion Research, Inc., Cambridge, Mass., model 99-20) (coefficient of variation $1.2 \%$ ) (32). Control subjects showed no history of bone or kidney disease and they had normal serum concentrations of calcium (total and ionized) (Fig. 7), as well as phosphorus, alkaline phosphatase, creatinine, and iPTH (unpublished results and reference 23). iPTH was determined in a heterologous system ([ $\left.{ }^{181} \mathrm{I}\right] \mathrm{bPTH}-(1-84)$, guinea pig anti-pPTH GP1M diluted $1: 100,000,{ }^{\circ}$ and a hPTH culture standard C-72) as described by Arnaud, Tsao, and Littledike (4). GP1M antiserum and C-72 standard were kindly provided by Dr. C. D. Arnaud. Sera from patients with surgically verified primary hyperpara-

- All antisera dilutions indicated in this publication refer to serum concentration in the final incubation mixture of $0.5 \mathrm{ml}$. thyroidism had increased serum calcium concentrations (Fig. 7). iPTH was quantitated by means of the following systems :

(a) [180I]bPTH-(1-84), anti-hPTH-(TCA) (goat 3, day 253, diluted $1: 1,500)$ and hPTH-(1-84)G-100 as standard.

(b) [ $\left.{ }^{181} \mathrm{I}\right] \mathrm{hPTH}-(1-34)$, anti-hPTH-(1-34) (goat 11, day 116 , diluted $1: 200,000)$ and hPTH- $(1-34)$ as standard.

Undiluted or diluted sera in quantities of $0.2,0.1$, and $0.05 \mathrm{ml}$ were added to the incubation system (total volume $0.5 \mathrm{ml}$ ). Control tubes with no antiserum containing 0.2 or $0.1 \mathrm{ml}$ of the unknown serum served to correct for nonspecific "binding." In addition, control tubes in quadruplicate with and without antiserum containing $0.2,0.1$, and $0.05 \mathrm{ml}$ serum obtained from patients with hypoparathyroidism after thyroidectomy were included in every assay. On no occasion did this control serum influence the $B / F$ ratios. Intra-assay and interassay coefficients of variation amounted to 7 and $12 \%$, respectively. Coefficients of variation were calculated according to Diem and Lentner (33).

\section{RESULTS}

Antibodies to extracted hPTH. As shown in Table I, hPTH-(TCA) is immunogenic. Specific binding of the two radioiodinated peptides used, however, was negligible during the first 15 wk after primary immunization. The capacity to bind $\left[{ }^{21} \mathrm{I}\right] \mathrm{bPTH}-(1-84)$ but not $\left[{ }^{21} \mathrm{I}\right] \mathrm{hPTH}-(1-34)$ was found to increase considerably after a second injection of the antigen on day 107. Serum samples obtained from goat 3 after additional reimmunizations on days 205 and 244 exhibited enhanced reactivity with both trace-labeled preparations. A final injection on day $\mathbf{3 0 0}$ did not cause further augmentation of the antigen binding capacity.

The qualitative properties of goat anti-hPTH-(TCA) were found to depend on the assay system employed. This is apparent from Table II in which the IDso values of three inhibitors are recorded for two trace-labeled ligands. As judged by the amounts of inhibitor neces- 
TABLE V

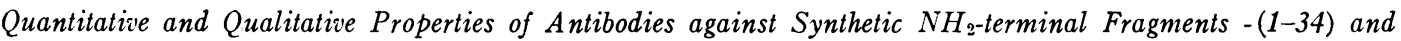
-(1-12) of human parathyroid hormone. Dependance on the $\mathrm{pH}$ of the Incubation Medium

\begin{tabular}{|c|c|c|c|c|c|c|c|c|c|}
\hline \multirow[b]{2}{*}{ Goat } & \multirow[b]{2}{*}{ Antigen* } & \multicolumn{8}{|c|}{$\mathrm{pH}$} \\
\hline & & 5.0 & & 6. & & 7.4 & & 8.6 & \\
\hline & $\mu g$ & & $n g$ & & $n g$ & & $n g$ & & $n g$ \\
\hline 8 & 330 hPTH-(1-12) & $390 \ddagger$ & $1.15 \S$ & 640 & ND & 660 & ND & 610 & 0.39 \\
\hline 10 & 35 hPTH-(1-34) & 2,900 & 0.38 & 5,900 & ND & 15,000 & ND & 18,000 & 0.06 \\
\hline 11 & 280 hPTH-(1-34) & 18,000 & 0.16 & 23,000 & ND & 64,000 & ND & 75,000 & 0.09 \\
\hline
\end{tabular}

* Goat 8: injected on days 0 and 107 . Goats 10 and $11:$ injected on days 0 and 112 . Antisera were obtained on Day 116. ND, not done.

$\ddagger$ Reciprocal dilution-50 (homologous system).

$\S$ Inhibition dose-50 (homologous system).

sary for a $50 \%$ reduction of specific binding of $\left[{ }^{131} \mathrm{I}\right]$ hPTH-(1-34) to antibody against hPTH-(TCA), the synthetic fragment hPTH-(1-34) was a more potent inhibitor than the extracted full-length peptides of human or bovine origin. Although the ID $\mathrm{D}_{50}$ of hPTH(1-84) and the IDso of bPTH-(1-84) were of the same order of magnitude, the inhibition patterns of these peptides were different. On the other hand, all the human peptides displayed a qualitatively identical type of inhibition (Fig. 2, left panel). The results were different when $\left[{ }^{131} \mathrm{I}\right] \mathrm{bPTH}-(1-84)$ was used as the labeled ligand. As shown in Table II and Fig. 2 (right panel), synthetic hPTH-(1-34) in quantities as high as $5 \mu \mathrm{g}$ had no inhibitory effect in this system. The extractive 1-84-peptide of both species exhibited similar inhibition patterns, but bPTH-(1-84) was a somewhat more potent inhibitor than hPTH-(1-84)G-100 and hPTH(TCA).
As assessed with [ $\left.{ }^{131} \mathrm{I}\right] \mathrm{bPTH}-(1-84)$ and anti-hPTH(TCA) with hPTH-(1-84)G-100 as standard, the purity of extracted hPTH-(TCA) was estimated to range between 1.0 and $1.1 \%$ (Table III).

Antibodies to synthetic $\mathrm{NH}_{2}$-terminal fragment -(112) of $h P T H$. Antibody activity in sera from goats immunized with hPTH-(1-12) was rather low after the primary injection. As shown in Table IV, only two goats receiving $330 \mu \mathrm{g}$ of antigen had circulating antibodies in their sera when sampled on day 56. 9 days after a second injection of antigen, sera from two animals of the same group exhibited reciprocal dilution-50 values of 60 and 400 . None of the sera from goats injected with $40 \mu \mathrm{g}$ of the peptide on days 0 and 107 bound $50 \%$ of trace-labeled hPTH-(1-12) at dilutions as low as $1: 10$. Inhibition doses-50 were determined on only a few occasions and were rather high, except in the case of antiserum from goat 8 (day 116).
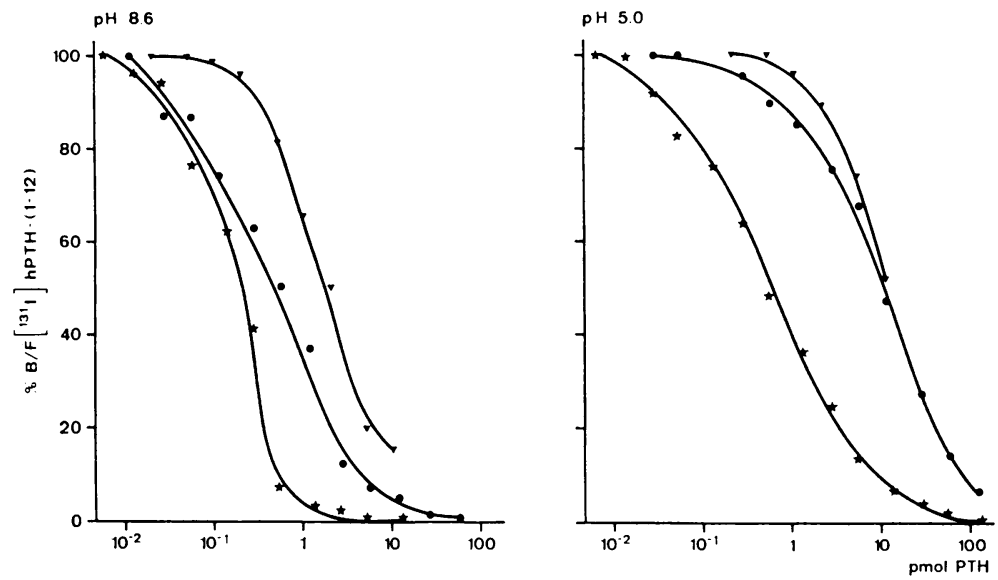

FIgURE 3 Qualitative properties of antibodies to synthetic hPTH-(1-12). Inhibition of specific binding of $\left[{ }^{13} \mathrm{I}\right] \mathrm{hPTH}-(1-12)$ at $\mathrm{pH} 8.6$ (left) and at $\mathrm{pH} 5.0$ (right) to anti-hPTH-(1-12) obtained from goat 8 , day 116, (see Table V) and diluted $1: 1,500$. Ordinate: percent initial

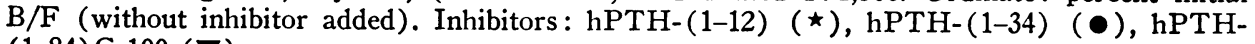
$(1-84)$ G-100 ( $\boldsymbol{\nabla})$. 


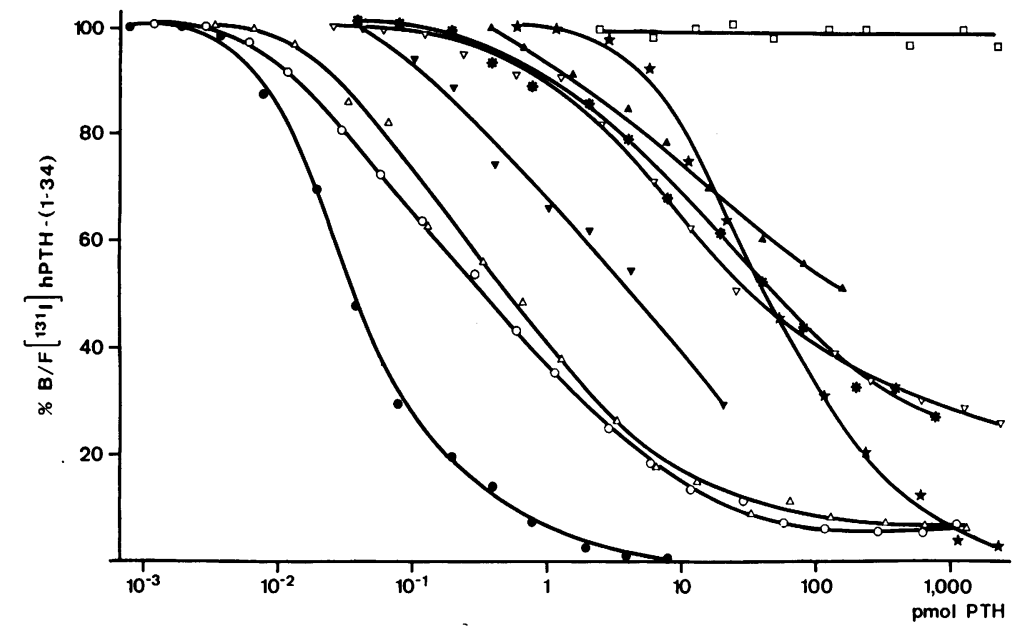

FIGURE 4 Qualitative properties of antibodies to synthetic hPTH-(1-34). Inhibition of specific binding of [ I I]hPTH-(1-34) to anti-hPTH-(1-34) obtained from goat 10, day 26 (after primary immunization with $35 \mu \mathrm{g} \mathrm{hPTH}-(1-34)$ and diluted $1: 10,000)$. Ordinate: percent initial $\mathrm{B} / \mathrm{F}$ (without inhibitor added). Inhibitors: hPTH-(1-34) $(\bullet),-(13-34)(\mathrm{O}),-(18-$ 34) $(\Delta),-(25-34)(\nabla),-(1-12)(\star),-(18-24)(\square),-(1-84)(\nabla)$, as well as bPTH$(1-34)(*)$ and $-(1-84)(\Delta)$.

The quantitative and qualitative properties of antihPTH-(1-12) from goat 8 (day 116) were assessed at various $\mathrm{pH}$ levels, since $\mathrm{pH}$ may alter the immunological interactions of peptides with their antibodies by changing conformational properties $(21,34,35)$. Dilution-50 was lowest at $\mathrm{pH} 5$ and was found to be increased by a factor of approximately 1.6 at $\mathrm{pH}$ 6.2-8.6. On the other hand, the IDso of hPTH-(1-12) decreased by a factor of 2.9 when the $\mathrm{pH}$ was raised from 5.0 to 8.6 (Table V, first line). The inhibition patterns obtained with the homologous peptide hPTH-(1-12) and with hPTH-(1-34) and hPTH-(1-84) are shown in Fig. 3. The differences seen at $\mathrm{pH}$ levels of 8.6 and 5.0 can also be expressed in terms of relative molar inhibition. Thus, the IDso's of hPTH-(1-34) and -(1-84) relative to $\mathrm{hPTH}-(1-12)$ are 2.9 (at $\mathrm{pH} 8.6$ ) and 16.6 (at $\mathrm{pH}$ 5.0) and 11.5 (at $\mathrm{pH} 8.6$ ) and 18.3 (at $\mathrm{pH}$ $5.0)$, respectively.

Antibodies to synthetic $\mathrm{NH}_{\mathrm{s}-t e r m i n a l}$ fragment -(134) of $h P T H$. In a previous publication, we described the immune response to hPTH-(1-34) in goats and demonstrated that high-titer antibodies in sera were obtained as early as 26 days after primary immunization (23). As judged by ID $_{\text {so }}$ determinations, some of these antisera already had a rather strong affinity for the antigen. By day 116, 4 days after a second injection of hPTH-(1-34), sera from all the six goats immunized exhibited IDso values of approximately $30 \mathrm{pg}$, indicating that every antiserum was potentially utilizable for estimating $\mathrm{NH}_{2}$-terminal PTH activity radioimmunologically in unknown samples. In the present study, we investigated additional qualitative properties of two of these antisera. Fig. 4 shows the immunological specificity of the day-26 serum from goat 10 . As judged by the IDso values read from the graph, the $\mathrm{COOH}$ terminal fragments $-(13-34)$ and $-(18-34)$ inhibited the primary interaction of $\left.{ }^{121} \mathrm{I}\right] \mathrm{hPTH}-(1-34)$ with its antibody at concentrations approximately 10 times higher than the homologous inhibitor. On the other hand, a $50 \%$ inhibition by the $\mathrm{NH}_{2}$-terminal fragment $-(1-12)$ and the shortest COOH-terminal fragment tested, -(25-34), was only obtained at concentrations 1,000 times higher than those of hPTH-(1-34). The intermediary fragment -(18-24) did not inhibit at all, whereas full-length human extracted peptide had an ID 50 approximately 30 times higher than ID $_{50}$ of the homologous inhibitor. bPTH-(1-34) displayed an inhibition pattern similar to that of the COOH-terminal hPTH-(25-34), whereas the full-length peptide bPTH(1-84) showed somewhat less inhibitory activity.

The inhibition patterns of hPTH-(1-34) and -(1-12) were similar, whereas those of the other inhibitors were different. This is also shown on Fig. 5, which shows the qualitative properties of day- 26 antiserum from goat 11. It can be seen that the inhibition curves of hPTH-(1-34) and -(1-12) are superimposable. On the other hand, the quantitative inhibition of binding of $\left[{ }^{21} \mathrm{I}\right] \mathrm{hPTH}-(1-34)$ produced by hPTH-(18-34) and -(1-84)G-100 was different, but the qualitative patterns of inhibition produced by the two peptides were identical. Fig. 6 indicates the inhibition relative to hPTH-(1-34), summarizes the findings obtained with the day- 26 sera of goats 10 and 11 , and compares the immunological properties of these early sera with 
those of sera obtained on day 116,4 days after reimmunization. There are some changes in immunological specificity which, however, appear small or inconsistent in the case of the hPTH peptide series and somewhat greater in the case of bPTH-(1-34) and - (184). The relative inhibition induced by bovine peptides was considerably less with late than with early antisera.

As already described with regard to the $\left[{ }^{21} \mathrm{I}\right] \mathrm{hPTH}$ (1-12), anti-hPTH-(1-12) system, we studied properties of antibodies at different $\mathrm{pH}$ levels of the incubation mixture. Table $\mathrm{V}$ (2nd and 3rd line) shows that the antigen binding capacity was lowest at $\mathrm{pH} 5$ and increased by a factor of 6.2 and 4.2 when tested at $\mathrm{pH}$ 8.6. Correspondingly, the IDso values of hPTH-(1-34) were 60 and $90 \mathrm{pg}$ at $\mathrm{pH} 8.6$ as compared with 160 and $380 \mathrm{pg}$ at $\mathrm{pH}$ 5.0. However, the relative inhibition values obtained with various $\mathrm{PTH}$ peptides were generally comparable at $\mathrm{pH} 5.0$ and 8.6 (Fig. 6).

iPTH in peripheral sera of control subjects and of patients with primary hyperparathyroidism. iPTH was quantitated with [ $\left.{ }^{181} I\right] \mathrm{bPTH}-(1-84)$, anti-hPTH(TCA) and hPTH-(1-84)G-100 as standard in sera from 26 patients with surgically verified primary hyperparathyroidism and from 38 control subjects; iPTH was below the sensitivity of the assay $(0.04 \mathrm{ng} / \mathrm{ml})$ in three additional control sera. In 24 of the 26 patients with primary hyperparathyroidism iPTH was elevated, and there was a good discrimination between the two groups (Fig. 7C). On gel filtration of six hyperparathyroid sera, iPTH always eluted as a single peak between hPTH-(1-84) and -(1-34) (Fig. 8). Nevertheless, the inhibition curves of hyperparathyroid sera and the gel filtration peak fractions of these and hPTH(1-84)G-100 were superimposable, indicating immunological similarity (Fig. 9A).

iPTH was also estimated with [11]hPTH-(1-34), anti-hPTH-(1-34) and hPTH-(1-34) as standard and found to be measurable in every serum tested of 17 patients with primary hyperparathyroidism and in sera of 14 control subjects; iPTH was below the sensitivity of the assay $(0.014 \mathrm{ng} / \mathrm{ml})$ in sera from five additional control subjects. The mean iPTH levels were higher in patients with primary hyperparathyroidism than in control subjects. However, there was a large overlap between the two groups (Fig. 7D). Again, the inhibition curves of hyperparathyroid sera and hPTH-(134) were superimposable, indicating immunological similarity (Fig. 9B). On gel filtration (Fig. 8), three peaks could be distinguished; the first eluted shortly after the void volume and the second co-eluted with hPTH-(1-84), whereas the third was located in the hPTH-(1-34) region. A comparable pattern was observed as regards the first and second peaks in five additional gel-filtrated sera from patients with primary

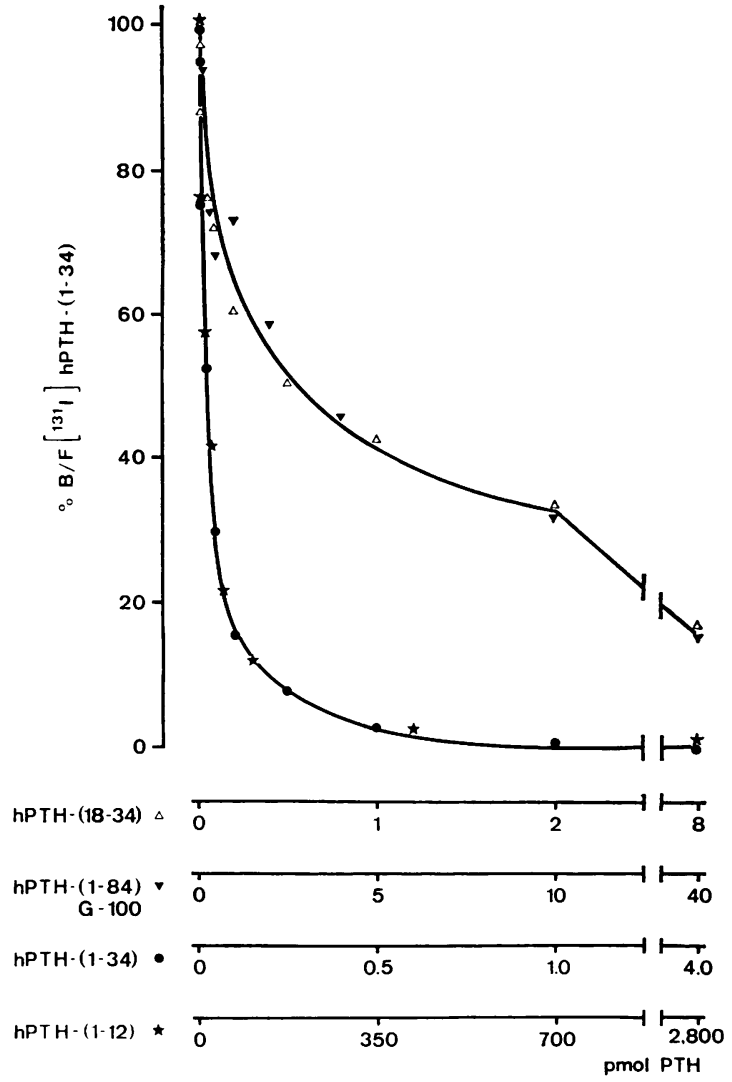

FIGURE 5 Qualitative properties of antibodies to synthetic $\mathrm{hPTH}-(1-34)$. Inhibition of specific binding of [ $\left.{ }^{131} \mathrm{I}\right] \mathrm{hPTH}-$ (1-34) to anti-hPTH-(1-34) obtained from goat 11, day 26 (after primary immunization with $280 \mu \mathrm{g} \mathrm{hPTH}-(1-34)$ and diluted 1:80,000). Ordinate: percent initial $\mathrm{B} / \mathrm{F}$ (without inhibitor added). Inhibitors: hPTH-(1-34) (๑), $-(1-12)(\star),-(1-84) \mathrm{G}-100(\nabla)$, and $-(18-34)(\Delta)$.

hyperparathyroidism, whereas a variable amount of immunoreactivity was recognized in later eluting fractions; the third peak sometimes trailed into the [ $\left.{ }^{211} \mathrm{I}\right]$ hPTH-(1-12) region.

\section{DISCUSSION}

Our present study was prompted by the availability of extracted hPTH in sufficiently large amounts and the availability of synthetic $\mathrm{NH}_{2}$-terminal fragments of hPTH comprising the first 34 amino acid residue and fragments thereof. For the first time, it was thus feasible to examine quantitatively and qualitatively the immune response of hPTH in animals and to use antibodies against the human hormone for estimating iPTH in sera obtained from patients suffering from primary hyperparathyroidism or in sera from normal subjects.

Antibodies to hPTH were induced in the goat, which has recently been shown to be very suitable for the production of large quantities of potent antibodies against

Antibodies to Human Parathyroid Hormone

1389 


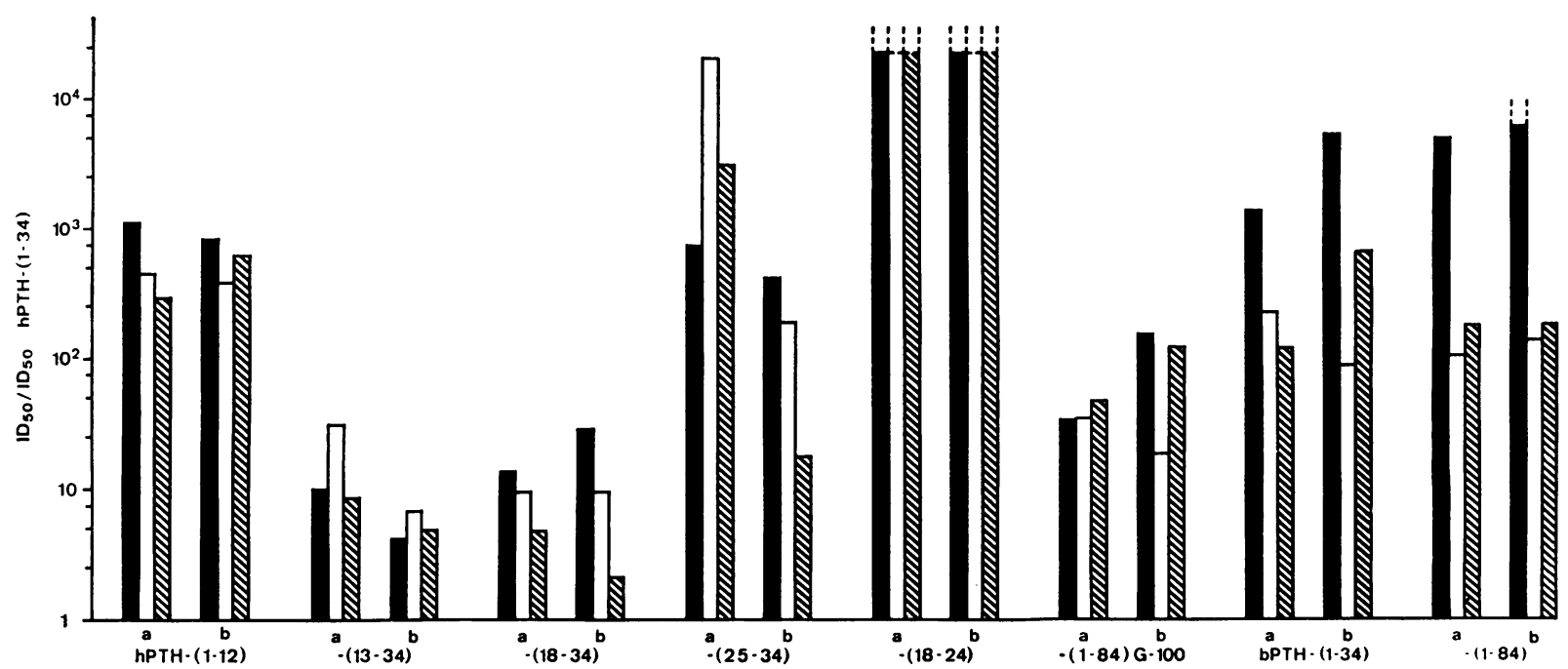

FIGURE 6 Qualitative properties of antibodies to synthetic hPTH-(1-34). Inhibition of specific binding of $\left[{ }^{131} \mathrm{I}\right] \mathrm{hPTH}-(1-34)$ to anti-hPTH-(1-34) obtained from goat 10 (denoted "a") and goat 11 (denoted "b"), day 26 (solid bars) and day 116 (open bars: pH 8.6, hatched bars : $\mathrm{pH} 5.0$ ). Goat 10 received $35 \mu \mathrm{g}$ of antigen on days 0 and 112, goat $11280 \mu \mathrm{g}$ on days 0 and 112. Ordinate: molar $\mathrm{ID}_{50}$ values relative to $\mathrm{ID}_{50}$ obtained with $\mathrm{hPTH}-(1-34)$.
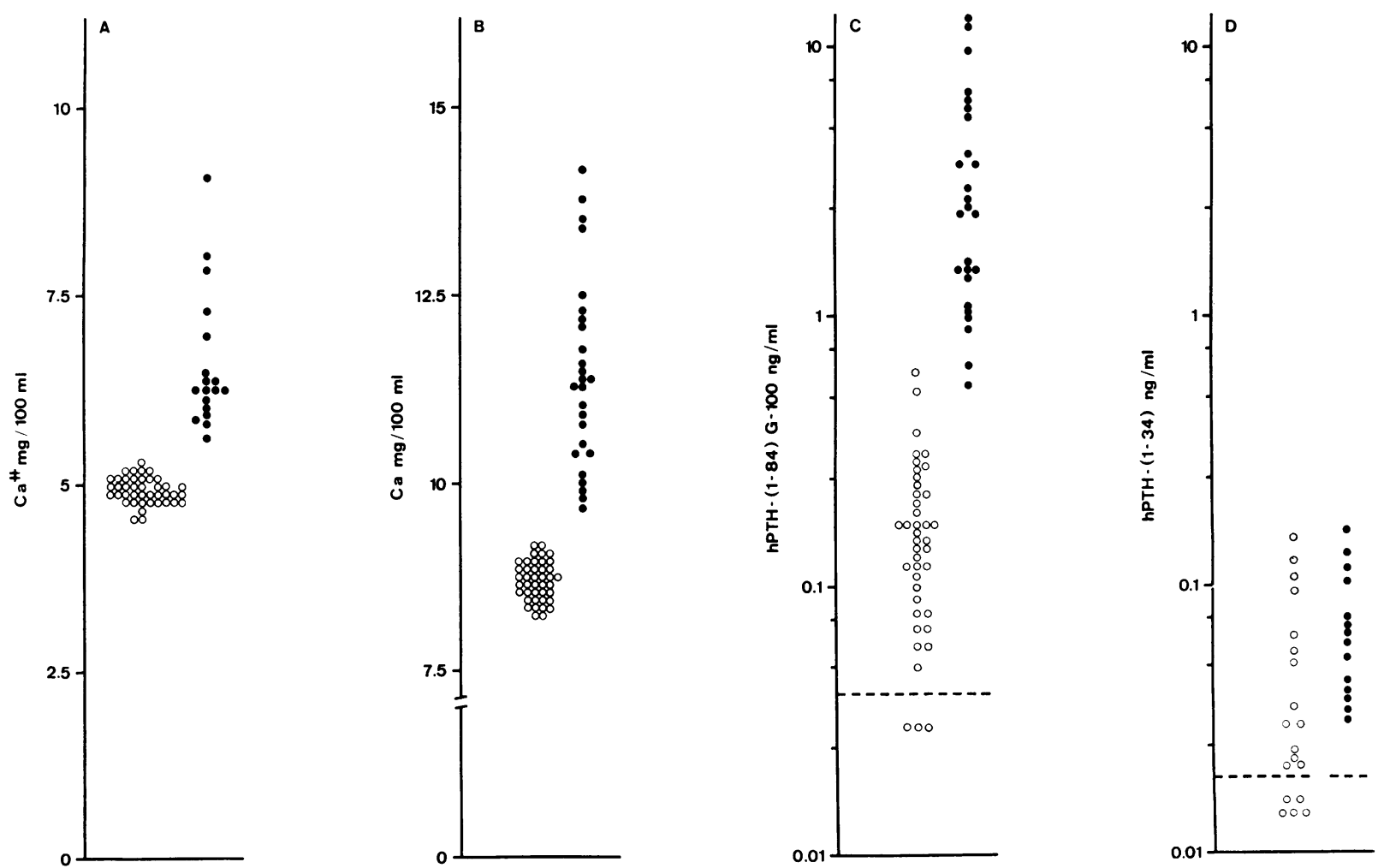

FIgURE 7 Serum calcium determination and radioimmunological estimation of iPTH in peripheral human serum. Control subjects $(O)$, patients with primary hyperparathyroidism (•). (A) Ionized calcium $\left(\mathrm{Ca}^{++}\right)$. Note that it has not been determined in all the patients studied. (B) EGTA-titrable calcium (Ca). (C) [ $\left.{ }^{121} \mathrm{I}\right] \mathrm{bPTH}-(1-84)$, anti-hPTH-(TCA) (goat 3, day 253, diluted $1: 1,500$ ), and hPTH-(1-84) G-100 as standard. (D) [ $\left.{ }^{181} \mathrm{I}\right] \mathrm{hPTH}-$ (1-34), anti-hPTH-(1-34) (goat 11 , day 116 , diluted $1: 200,000)$, and hPTH- $(1-34)$ as standard. The stippled lines indicate the sensitivity limits of the radioimmunoassays. 


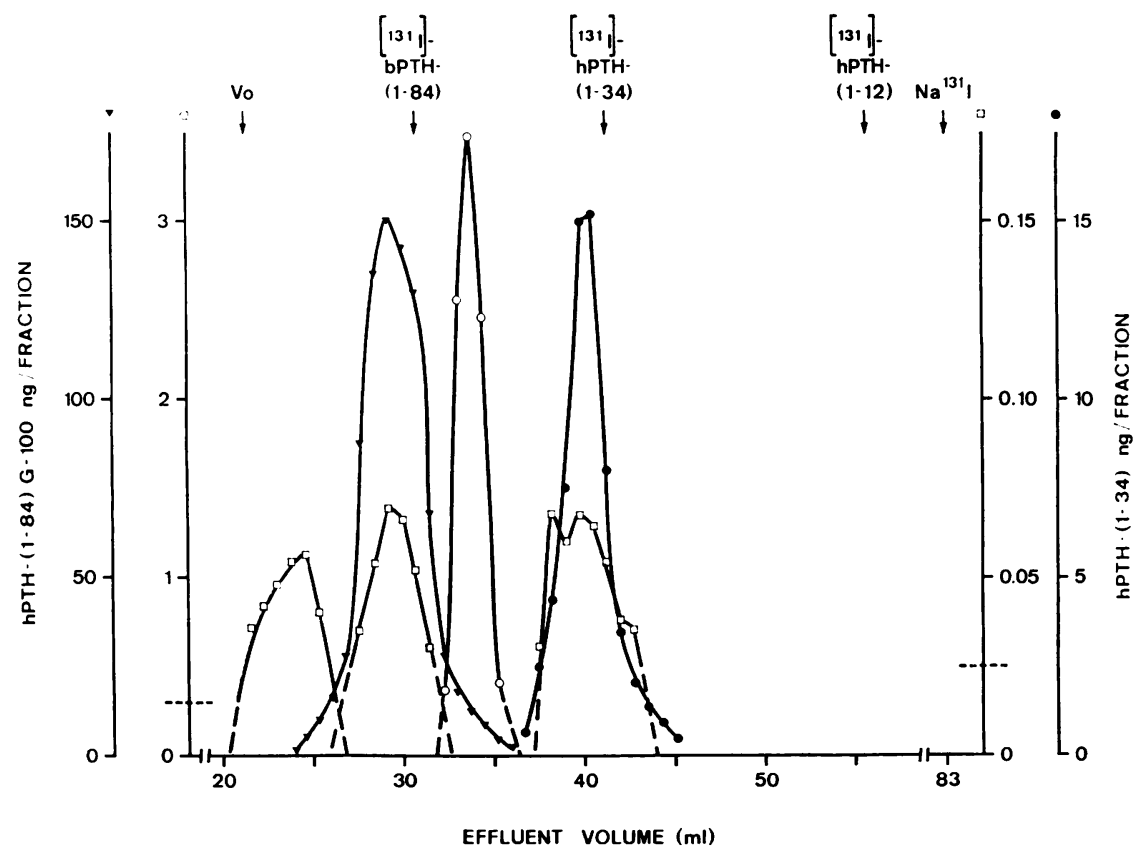

FIGURE 8 Characterization of hPTH-(TCA), hPTH-(1-34), and iPTH from a patient (L. A.) with primary hyperparathyroidism by chromatography on Bio-Gel P-10. [ $\left.{ }^{121} \mathrm{I}\right] \mathrm{bPTH}-$ (1-84), [ $\left.{ }^{131} \mathrm{I}\right] \mathrm{hPTH}-(1-34),\left[{ }^{181} \mathrm{I}\right] \mathrm{hPTH}-(1-12)$, and $\mathrm{Na}^{181} \mathrm{I}$ were added as tracer to $1-\mathrm{ml}$ samples of the dissolved peptides or serum. $1 \times 100-\mathrm{cm}$ column, $0.2 \mathrm{M}$ ammonium acetate, $\mathrm{pH}$ 4.7, and human serum albumin $2.5 \mathrm{mg} / \mathrm{ml}$ as eluant, $1.5 \mathrm{ml} / \mathrm{h}$ flow rate, $0.75-\mathrm{ml}$ fractions. hPTH-(TCA) ( $)$ : analyzed with [ $\left.{ }^{121} \mathrm{I}\right] \mathrm{bPTH}-(1-84)$, anti-hPTH-(TCA) (goat 3, day 253, diluted $1: 1,500)$, and hPTH-(1-84)G-100 as standard. hPTH-(1-34) (๑): analyzed with [131]]hPTH-(1-34), anti-hPTH-(1-34) (goat 11, day 116, diluted 1:200,000), and hPTH(1-34) as standard. iPTH (L. A.): analyzed with the [ $\left.{ }^{131} I\right] b P T H-(1-84)$, anti-hPTH(TCA) system (O) and with the [1910 I]hPTH-(1-34) anti-hPTH-(1-34) system ( $\square)$. The stippled line indicates the sensitivity limits of the radioimmunoassay.

synthetic human calcitonin ${ }^{5}$ and against a variety of other immunogens as well. Submilligram amounts of synthetic hPTH-(1-34), adsorbed onto aluminum hydroxide, incorporated into complete Freund's adjuvant and injected intradermally, induced high-titer antisera exhibiting reciprocal dilution-50 values of as high as almost $10^{5}$, whereas the IDso of $\mathrm{hPTH}-(1-34)$ was of the order of $0.05-0.1 \mathrm{ng}$. Extracted hPTH-(TCA), on the other hand, seemed to be less immunogenic, which probably was due to the comparatively smaller doses employed for immunization. As compared to the tetratriacontapeptide, the synthetic dodecapeptide was less immunogenic, the reciprocal dilution-50 values only reached levels of $20-400$ and the ${ }^{2} D_{50}$ 's ranged from 0.4 to more than $100 \mathrm{ng}$.

Antibodies to extracted hPTH-(TCA) were shown to be directed both to the $\mathrm{COOH}$-terminal and, albeit to a small extent, to the $\mathrm{NH}_{2}$-terminal part of the hPTH-(1-84) molecule and furthermore, when [ $\left.{ }^{151} \mathrm{I}\right]$ hPTH-(1-34) was used as the ligand, clearly discrimi-

${ }^{5}$ F. M. Dietrich and J. A. Fischer. In preparation. nated between the full-length human and bovine hormones.

The NHs-terminal dodecapeptide of hPTH, whose structure is undisputed and has been identically defined by two independent groups of workers $(20,24)$, was chosen to produce antibodies which would make it possible to estimate the short-lived $\mathrm{NH}_{2}$-terminal $\mathrm{PTH}$ fragments claimed to be present in human sera (17-19). In spite of the fact that the quantity and quality of the antibodies obtained against synthetic hPTH-(1-12) did not yet meet the prerequisites for a sensitive radioimmunoassay, it is felt that this system will be improved and will be useful for future clinical studies. Antibodies to hPTH-(1-12) were shown to have somewhat different immunochemical properties depending on the $\mathrm{pH}$ chosen for incubation. At $\mathrm{pH} 8.6$ and 5.0, the inhibition patterns obtained with hPTH-(1-12) were comparable and the IDso values were 0.2 and 0.6 pmol, respectively. Quite differently, hPTH-(1-34) had ID 1 values of 0.6 and 10 , and hPTH-(1-84)G-100 of 2.3 and $11 \mathrm{pmol}$ at these $\mathrm{pH}$ levels. These observations could indicate that hPTH-(1-84) and -(1-34) in solution possess some degree of ordered conformation 

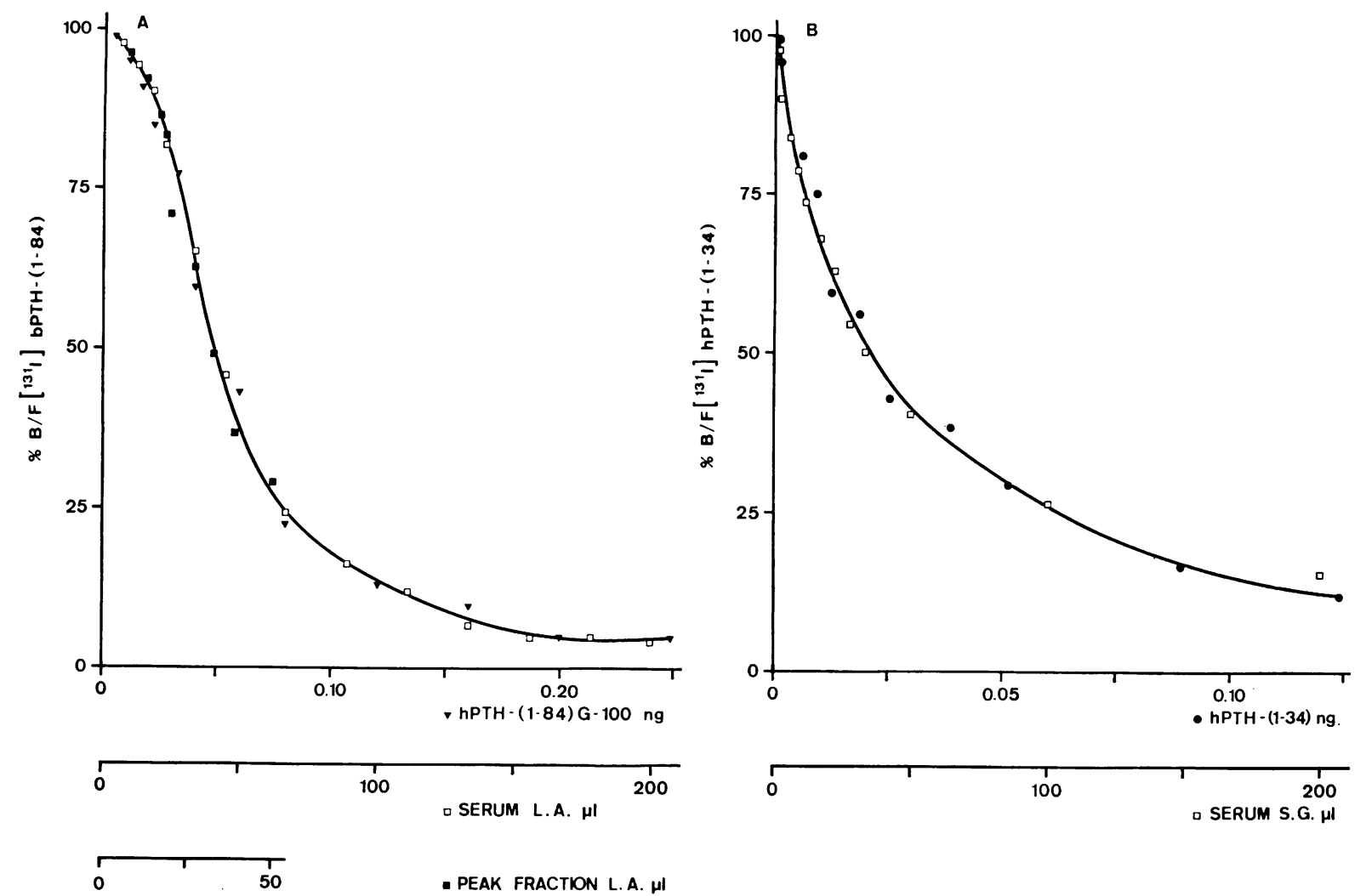

FIgURE 9 Immunological characterization of PTH from patients L. A. and S. G. with primary hyperparathyroidism. (A) Inhibition of specific binding of [ $\left.{ }^{12} \mathrm{I}\right] \mathrm{bPTH}-(1-84)$ to antihPTH-(TCA) (goat 3, day 253, diluted $1: 1,500$ ) by hPTH- $(1-84) \mathrm{G}-100(\nabla)$, serum from patient L. A. ( $\square$ ), and peak fraction after gel filtration ( $\square$ ) (for details see Fig. 8). (B) Inhibition of specific binding of [ $\left.{ }^{201} \mathrm{I}\right] \mathrm{hPTH}-(1-34)$ to anti-hPTH-(1-34) (goat 11, day 116, diluted $1: 200,000)$ by hPTH- $(1-34)(\bullet)$ and serum from patient S. G. ( $\square)$. Ordinate: percent initial $\mathrm{B} / \mathrm{F}$ (without inhibitor added).

which differs at $\mathrm{pH} 5.0$ from that at $\mathrm{pH}$ 8.6. A similar conclusion was reached by Brewer, Fairwell, Rittel, Littledike, and Arnaud (21).

The highly potent goat antibodies against synthetic hPTH-(1-34) are characterized by the presence of specificities located in several parts of the molecule, including the $\mathrm{COOH}$-terminal and $\mathrm{NH}_{2}$-terminal regions of the tetratriacontapeptide. The relative inhibition of the hPTH-(18-34) fragment as compared to hPTH(1-34) was rather low and varied between 2.5 and 30. The relative inhibition of the hPTH-(25-34) fragment, on the other hand, was high and ranged between 20 and 250,000. The hPTH-(18-24), however, did not inhibit at all in this system. Thus, it remains to be shown whether or not all the data presented can be explained solely by properties defined by primary peptide structures. Changes in the $\mathrm{pH}$ of the incubation mixture have not given consistent and and clear-cut results that would permit speculation as to the importance of conformational features for immunological specificity.

The immunochemical data reported in the present study are consistent with the view that synthetic amino terminal fragments $(20,22)$ and the native PTH are structurally identical at the corresponding regions. This has been demonstrated in particular with the ['I]hPTH-(1-34), anti-hPTH-(TCA) system, where inhibition curves of hPTH-(1-34) and -(1-84)G-100 were superimposable indicating immunological identity with the antiserum used. Similar qualitative findings have been made with the [ $\left.{ }^{21} \mathrm{I}\right] \mathrm{hPTH}-(1-34)$, antihPTH-(1-34) system with respect to the inhibitory properties of hPTH-(18-34) and -(1-84)G-100. We are, however, well aware that structural identity cannot be proven by immunochemical methodology.

The content of PTH in the circulation of man has been exclusively estimated by radioimmunological technics. A competitive binding assay employing ${ }^{111}$ I-tracelabeled bPTH, anti-bPTH, and plasma PTH as standard was introduced by Berson and Yalow (1). These authors noted a considerable overlap between the iPTH levels in plasma from hyperparathyroid and normal subjects. In addition, in $20 \%$ of the plasma specimens 
obtained from normal subjects, iPTH was undetectable. Similar findings were subsequently reported by various authors (3-8). Only Reiss and Canterbury (2) demonstrated a clear-cut discrimination between sera obtained from hypoparathyroid, normal, and hyperparathyroid subjects. Arnaud et al. (4) detected iPTH in $94 \%$ of their normal sera, but they also found that $10 \%$ of hyperparathyroid sera had iPTH levels within the same range as that present in normal sera. iPTH, however, was not detectable in hypercalcemic patients unless they were suffering from hyperparathyroidism. Our own results, obtained with [20I]bPTH-(1-84) and antihPTH-(TCA), showed a similar discrimination of iPTH and calcium (total and ionized) levels in serum of normal subjects and patients with primary hyperparathyroidism. Inhibition curves of hPTH-(1-84) and of hyperparathyroid sera were superimposable. Thus, iPTH values could be expressed in gravimetric terms by using hPTH-(1-84)G-100 as a standard, rather than by reference to a serum from a hyperparathyroid patient $(1,2,4,8)$. In this system, however, the $\mathrm{NH}_{2-}$ terminal fragment hPTH-(1-34) was not recognizable. Similar findings were reported by Silverman and Yalow (18) and by Arnaud et al. $(19,36)$, who employed an antibody against bPTH and pPTH, respectively. The results obtained in the present study with the second assay system used ([121]hPTH-(1-34) and antihPTH-(1-34)) were in marked contrast. As compared with those found in the first assay system described above, the iPTH levels in the sera of normal and hyperparathyroid subjects largely overlapped. This finding parallels results obtained with anti-bPTH, exhibiting specificities primarily directed against $\mathrm{NH}_{2}$-terminal parts of the full-length PTH peptide $(18,19,36)$. It thus appears that the radioimmunological diagnosis of hyperparathyroidism can best be made by employing antibodies directed to $\mathrm{COOH}$-terminal parts of hPTH(1-84), thus confirming the findings of Arnaud, Goldsmith, Bordier, and Sizemore (19).

A great obstacle in quantitating $\mathrm{PPTH}$ in human sera is the presence of PTH peptides with different molecular weights (13-19). Upon gel filtration of the incubation media of cultured explants of parathyroid adenomas, iPTH species with molecular weights ranging from 5,000 to greater than 10,000 daltons were observed $(11,12)$. Analysis by gel chromatography of hyperparathyroid sera showed that the major species of $\mathrm{iPTH}$ in venous effluents from parathyroid adenomas represented glandular hPTH-(1-84), whereas the major species of $\mathrm{iPTH}$ in the peripheral circulation had a molecular weight of approximately 7,000 (13) and lacked $\mathrm{NH}_{2}$-terminal parts of the hPTH-(1-84) molecule $(15,16,18,19)$. This would explain why the [MI]hPTH-(1-34), anti-hPTH-(1-34) system is not suitable for the estimation of $\mathrm{PTH}$ in hyperparathyroid sera. Canterbury and Reiss (14) detected three molecular-weight classes of PTH in sera of hyperparathyroid patients. Besides components with molecular weights of 9,500 and $7,000-7,500$, the authors described a class of iPTH having a molecular weight of $4,500-5,000$. It is interesting to note that iPTH with molecular weight lower than 6,000 were mainly recognizable with antibodies to bPTH exhibiting $\mathrm{NH}_{2}$-terminal specificities $(17-19,36)$. These results are confirmed and extended by the data we obtained by using antibodies to synthetic hPTH-(1-34) to analyze gel filtration eluates from hyperparathyroid sera. The findings are consistent with the presence of biologically active $\mathrm{NH}_{-}$-terminal fragments in the circulation as demonstrated by Canterbury, Levey, and Reiss (37). Our findings are furthermore consistent with the possibility that certain adenomas of the parathyroid secrete an $\mathrm{PTH}$ which has a larger molecular weight than hPTH- $(1-84)(12,38)$. The existence of precursor(s) of hPTH-(1-84) has been recently reported $(39,40)$.

\section{ACKNOWLEDGMENTS}

The excellent technical assistance of Miss M. Balzer, Miss K. Einsle, Miss M. Eschler, Mr. W. Hunziker, Miss M. Schulz, and Mrs. K. Wuethrich is gratefully acknowledged.

\section{REFERENCES}

1. Berson, S. A., and R. S. Yalow. 1966. Parathyroid hormone in plasma in adenomatous hyperparathyroidism, uremia, and bronchogenic carcinoma. Science (Wash. D. C.). $154:$ 907-909.

2. Reiss, E., and J. M. Canterbury. 1968. A radioimmunoassay for parathyroid hormone in man. Proc. Soc. Exp. Biol. Med. 128: 501-504.

3. Lequin, R. M., W. H. L. Hackeng, and W. Schopman. 1970. A radioimmunoassay for parathyroid hormone in man. II. Measurement of parathyroid hormone concentrations in human plasma by means of a radioimmunoassay for bovine hormone. Acta Endocrinol. 63: $655-666$.

4. Arnaud, C. D., H. S. Tsao, and T. Littledike. 1971. Radioimmunoassay of human parathyroid hormone in serum. J. Clin. Invest. 50: 21-34.

5. Potts, J. T., Jr., T. M. Murray, M. Peacock, H. D. Niall, G. W. Tregear, H. T. Keutmann, D. Powell, and L. J. Deftos. 1971. Parathyroid hormone: sequence, synthesis, immunoassay studies. Am. J. Med. 50: 639649.

6. Roof, B. S., G. S. Gordan, L. Goldman, and C. F. Piel. 1973. Berson and Yalow's radioimmunoassay for parathyroid hormone: a clinical progress report. Mt. Sinai J. Med. 40: 433-447.

7. Blair, A. J., Jr., C. D. Hawker, and R. D. Utiger. 1973. Ectopic hyperparathyroidism in a patient with metastatic hypernephroma. Metab. (Clin. Exp.). 22: $147-154$

8. Conaway, H. H., and C. S. Anast. 1974. Double-antibody radioimmunoassay for parathyroid hormone. $J$. Lab. Clin. Med. 83: 129-138. 
9. Berson, S. A., and R. S. Yalow. 1968. Immunochemical heterogeneity of parathyroid hormone in plasma. $J$. Clin. Endocrinol. Metab. 28: 1037-1047.

10. Arnaud, C. D., H. S. Tsao, and S. B. Oldham. 1970. Native human parathyroid hormone: an immunochemical investigation. Proc. Natl. Acad. Sci. U. S. A. 67: 415422.

11. Sherwood, L. M., J. S. Rodman, and W. B. Lundberg. 1970. Evidence for a precursor to circulating parathyroid hormone. Proc. Natl. Acad. Sci. U. S. A. 67 : $1631-1638$.

12. Arnaud, C. D., G. W. Sizemore, S. B. Oldham, J. A. Fischer, H. S. Tsao, and E. T. Littledike. 1971. Human parathyroid hormone: glandular and secreted molecular species. Am. J. Med. 50: 630-638.

13. Habener, J. F., D. Powell, T. M. Murray, G. P. Mayer, and J. T. Potts, Jr. 1971. Parathyroid hormone: secretion and metabolism in vivo. Proc. Natl. Acad. Sci. U. S. A. 68 : 2986-2991.

14. Canterbury, J. M., and E. Reiss. 1972. Multiple immunoreactive molecular forms of parathyroid hormone in human serum. Proc. Soc. Exp. Biol. Med. 140: 13931398.

15. Habener, J. F., G. V. Segre, D. Powell, T. M. Murray, and J. T. Potts, Jr. 1972. Immunoreactive parathyroid hormone in circulation of man. Nat. (New Biol.). 238: 152-154.

16. Segre, G. V., J. F. Habener, D. Powell, G. W. Tregear, and J. T. Potts, Jr. 1972. Parathyroid hormone in human plasma. Immunochemical characterization and biological implication. J. Clin. Invest. 51: 3163-3172.

17. Goldsmith, R. S., J. Furszyfer, W. J. Johnson, A. E. Fournier, G. W. Sizemore, and C. D. Arnaud. 1973. Etiology of hyperparathyroidism and bone disease during chronic hemodialysis. III. Evaluation of parathyroid suppressibility. J. Clin. Invest. 52: 173-180.

18. Silverman, R., and R. S. Yalow. 1973. Heterogeneity of parathyroid hormone. Clinical and physiologic implications. J. Clin. Invest. 52: 1958-1971.

19. Arnaud, C. D., R. S. Goldsmith, P. J. Bordier, and G. W. Sizemore. 1974. Influence of immunoheterogeneity of circulating parathyroid hormone on results of radioimmunoassays of serum in man. Am. J. Med. 56: 785-793.

20. Brewer, H. B., Jr., T. Fairwell, R. Ronan, G. W. Sizemore, and C. D. Arnaud. 1972. Human parathyroid hormone: amino-acid sequence of the amino-terminal residues 1-34. Proc. Natl. Acad. Sci. U. S. A. 69: 3585-3588.

21. Brewer, H. B., Jr., T. Fairwell, W. Rittel, T. Littledike, and C. D. Arnaud. 1974. Recent studies on the chemistry of human, bovine, and porcine parathyroid hormones. Am. J. Med. 56: 759-766.

22. Andreatta, R. H., A. Hartmann, A. Jöhl, B. Kamber, R. Maier, B. Riniker, W. Rittel, and P. Sieber. 1973. Synthese der Sequenz 1-34 von menschlichem Parathormon. Helv. Chim. Acta. 56: 470-473.

23. Fischer, J. A., U. Binswanger, W. Rittel, and F. M. Dietrich. 1974. Human parathyroid hormone: immunological characterization of antibodies against the synthetic amino-terminal fragment 1-34, and their use in the determination of immunoreactive hormone in human sera. In Endocrinology 1973. S. Taylor, editor. W. Heineman, Ltd., London. 229-237.

24. Niall, H. D., R. T. Sauer, J. W. Jacobs, H. T. Keutmann, G. V. Segre, J. L. H. O'Riordan, G. D. Aurbach, and J. T. Potts, Jr. 1974. The amino-acid se- quence of the amino-terminal 37 residues of human parathyroid hormone. Proc. Natl. Acad. Sci. U. S. A. $71: 384-388$.

25. O'Riordan, J. L. H., P. M. Barling, G. N. Hendy, H. T. Keutmann, J. W. Jacobs, R. T. Sauer, H. D. Niall, G. Tregear, J. T. Potts, and G. D. Aurbach. 1973. Isolation of human parathyroid hormone and determination of the amino-acid sequence of the aminoterminal part of the molecule. Eur. J. Clin. Invest. 3: 259. (Abstr.)

26. Tregear, G. W., J. van Rietschoten, E. Greene, H. D. Niall, H. T. Keutmann, J. A. Parsons, J. L. H. O'Riordan, and J. T. Potts, Jr. 1974. Solid-phase synthesis of the biologically active N-terminal 1-34 peptide of human parathyroid hormone. Hoppe Seyler's Z. Physiol. Chem. 355: 415-421.

27. Rasmussen, H., Y. L. Sze, and R. Young. 1964. Further studies on the isolation and characterization of parathyroid polypeptides. J. Biol. Chem. 239: 28522857.

28. Hunter, W. M., and F. C. Greenwood. 1962. Preparation of iodine-131 labeled human growth hormone of high specific activity. Nature (Lond.). 194: 495-496.

29. Berson, S. A., and B. S. Yalow. 1966. Iodoinsulin used to determine specific activity of iodine-131. Science (Wash. D. C.). 152: 205-207.

30. Yalow, R. S., and S. A. Berson. 1960. Immunoassay of endogenous plasma insulin in man. J. Clin. Invest. 39 : 1157-1175.

31. Herbert, V., K.-S. Lau, C. W. Gottlieb, and S. J. Bleicher. 1965. Coated charcoal immunoassay of insulin. J. Clin. Endocrinol. Metab. 25: 1375-1384.

32. Studer, O., M. Knob, and U. Binswanger. 1972. Kalziumionenkonzentration im Serum. Schrveiz. Med. Wochenschr. 102 : 305-309.

33. Diem, K., and C. Lentner. 1968. Documenta Geigy, wissenschaftliche Tabellen. J. R. Geigy, Basel. 7th edition. 160.

34. Brewer, H. B., Jr. 1972. Chemistry and conformation of the bovine parathyroid hormone. In Endocrinology 1971. S. Taylor, editor. W. Heinemann, Ltd., London. 324-332.

35. Aloj, S., and H. Edelhoch. 1972. Structural studies on polypeptide hormones. II. Parathyroid Hormone. Arch. Biochem. Biophys. 150: 782-785.

36. Arnaud, C. D., R. S. Goldsmith, G. W. Sizemore, S. B. Oldham, J. Bischoff, J. A. Larsen, and P. Bordier. 1973. Studies on characterization of human parathyroid hormone in hyperparathyroid serum: practical considerations. Excerpta Med. Int. Congr. Ser. 270: 281-290.

37. Canterbury, J. M., G. S. Levey, and E. Reiss. 1973. Activation of renal cortical adenylate cyclase by circulating immunoreactive parathyroid hormone fragments. J. Clin. Invest. 52: 524-527.

38. Martin, T. J., P. B. Greenberg, and V. Michelangeli. 1973. Synthesis of human parathyroid hormone by cultured cells : evidence for release of prohormone by some adenomata. Clin. Sci. (Oxf.). 44: 1-8.

39. Habener, J. F., B. Kemper, J. T. Potts, Jr., and A. Rich. 1972. Proparathyroid hormone: biosynthesis by human parathyroid adenomas. Science (Wash. D. C.). $178: 630-633$.

40. Chu, L. L. H., R. R. MacGregor, P. I. Liu, J. W. Hamilton, and D. V. Cohn. 1973. Biosynthesis of proparathyroid hormone and parathyroid hormone. by human parathyroid glands. J. Clin. Invest. 52: 3089-3094. 